\title{
PARTISIPASI PEREMPUAN DALAM DUNIA PARIWISATA
}

\author{
Oleh: Haslinda \\ Dosen Tetap Pada Jurusan Syari'ah Stain Watampone
}

\section{Abstract:}

Many women workers engaged in various activities in the tourism sector, but gender issues are always attached to them which limit womens' activities in the public domain such as various forms of marginalization, discrimination, and subordination that was reflected in the inequality of wages or salaries. Dual role for women workers into a dilemma, on one hand they are as housewives who have excellent troubleshooting and households, on the other hand they must be professional in a career.

Keywords: women worker, tourism sector, marginalization, discrimination, subordination.

\begin{abstract}
Abstrak:
Pekerja perempuan banyak terlibat dalam berbagai kegiatan pada sektor pariwisata, tetapi berbagai permasalahan gender selalu menyertainya yang membatasi aktivitas kaum perempuan di ranah publik seperti berbagai bentuk marjinalisasi, diskriminasi, dan subordinasi yang tercermin pada kesenjangan upah dan gaji. Peran ganda bagi pekerja perempuan menjadi dilematis, disatu sisi mereka sebagai ibu rumah tangga yang harus piawai mengatasi masalah rumah tangga dan di sisi lain mereka harus profesional dalam berkarier.
\end{abstract}

Kata kunci: Pekerja perempuan, sektor pariwisata, marginalisasi, diskriminasi, subordinasi.

\section{PENDAHULUAN}

Pembukaan Konstitusi selaku Hukum Dasar Tertulis (UUD 1945), menyebut membebaskan bangsa dari penjajahan, membangun Indonesia yang merdeka bersatu berdaulat adil dan makmur. Juga melindungi segenap bangsa dan tumpah darah Indonesia. Berbagai pasal tentang HAM, seperti eksplisit ter-rumus dalam pasal 27 menunjuk kesamaan kedudukan warga negara di dalam hukum dan pemerintahan, serta haknya atas pekerjaan dan penghidupan yang layak. Substansi konstitusi menyiratkan kesamaan hak dan kewajiban bagi perempuanserupa dengan pria. Warga negara patut saling menerima, hormat menghormati dan membela hak baik pria maupun wanita. Dalam satu dekade terakhir, destinasi internasional khususnya pada Negara berkembang seperti Indonesia mulai melakukan diversifikasi objek wisata dengan 
memberdayakan pengembangan wisata altematif sebagai dampak dari peningkatan dampak negatif dari wisata massal.

Dunia pariwisata Indonesia sudah memperlihatkan perkembangan dengan pesat. Hal ini dapat dilihat dari banyaknya angkatan kerja baik untuk pria maupun perempuan. Banyaknya keikut sertaan perempuan yang bekerja di sektor pariwisata, terutama di dunia pariwisata sangatlah pesat. Pekerja perempuan yang terjun di dunia industri jasa pariwisata, ada yang masih lajang maupun ada yang sudah menikah. Peran ganda bagi perempuan yang sudah menikah dan bekerja di dunia pariwisata mempunyai problematika tersendiri, dimana mereka bekerja juga harus merawat keluarga.

Mengkaji perempuan bekerja tentu terkait dengan persoalan penyetaraan jender. Dalam pengertian ilmu sosial, istilah jender diartikan sebagai pola hubungan atau relasi laki-laki dan perempuan yang didasarkan kepada ciri-ciri sosial masing-masing. Tercakup di dalamnya pembagian kerja, pola relasi kuasa perilaku, dan persepsi yang membedakan laki-laki dengan perempuan. Sebagai pranata sosial jender bukan sesuatu yang baku dan tidak berlaku universal dalam artian berbeda dari satu masyarakat ke masyarakat lainnya dan dari waktu ke waktu lainnya, sehingga dalam pengertian tersebut jender sesungguhnya lebih berkaitan dengan sistem sosial masyarakat dan jauh lebih luas dari sekedar isu perempuan saja (Hafidz, 1995).

Demikian juga Fakih (1996)menyatakan jender adalah perbedaan jenis kelamin yang bukan biologis dan bukan kodrat Tuhan. Perbedaan biologis jenis kelamin merupakan kodrat Tuhan sehingga secara permanen dan universal berbeda. Sementara jender adalah behavioral differences antara laki-laki dan perempuan yang socialy constructed, yakni berbedaan yang bukan kodrat atau bukan ciptaan Tuhan, melainkan diciptakan baik oleh kaum laki-laki maupun perempuan melalui proses sosial dan budaya yang berkesinambungan.

Dapat ditegaskan bahwa perbedaan perilaku antara laki-laki dan perempuan selain yang biologis, sebagian besar justru terbentuk melalui proses sosial dan budaya atau kultural. Oleh karenanya jender berubah dari waktu ke waktu dari tempat ke tempat bahkan dari kelas ke kelas masyarakat, sementara jenis kelamin tidak berubah.

Secara teoritis peningkatan peran wanita sudah banyak mencapai hasil dan kemajuan. Akan tetapi pengakuan tersebut masih bersifat umum, pengakuan yang bersifat khusus terhadap berbagai kelompok wanita masih belum terlihat (Iqbal, 1994). Pengakuan yang tidak simpatik terhadap kaum perempuan, yaitu masih adanya anggapan bahwa perempuan adalah kaum yang 
lemah dibandingkan dengan laki-laki. Jika anggapan ini benar dan terus berlaku di masyarakat konsekuensinya perempuan akan selalu dinomerduakan setelah laki-laki. Berarti yang baik-baik selalu diperoleh lebih dahulu oleh laki-laki baru setelah itu perempuan. Secara moral anggapan tersebut tidak benar karena perempuan juga manusia seperti laki-laki.

Kini perempuan Indonesia banyak yang mengalami kemajuan, tidak hanya di tingkat rumah tangga, tetapi jauh di luar itu mereka berperan sebagai pengambil keputusan. Beberapa posisi strategis yang diduduki oleh perempuan Indonesia seperti presiden, menteri, anggota parlemen, public relation manager, front office manager, human relation director dan masih banyak lagi jabatan publik lainnya. Tenaga kerja perempuan cukup banyak juga yang terjun ke dunia pendidikan, mengabdikan dirinya sebagai tenaga pengajar baik sebagai guru, dosen maupun rektor. Bahkan jika ditinjau secara menyeluruh ternyata pekerja perempuan banyak juga sebagai pekerja yang digolongkan keras, dimana mereka bekerja sebagai supir, tukang bangunan, bengkel alat-alat berat dan lain-lain.

\section{PEMBAHASAN}

Dalam kehidupan riil, ideologi gender mempengaruhi tingkah laku \& pilihan-pilihan perempuan dan laki-laki yang menentukan hubungan sosial-ekonomi diantara mereka dalam masyarakat (termasuk dalam dunia kerja). Menurut Humphrey (Saptari \& Holzner, 1997;207), "dalam dunia kerja, identitas gender dalam dunia kerja sangat dipengaruhi oleh berbagai stereotype yang umumnya menempatkan laki-laki sebagai nafkah utama, pekerja trampil, bertenaga kuat, dan berkompetensi teknis. Sebaliknya perempuan sebagai pekerja sekunder, tidak trampil, berfisik lemah, dan tidak mempunyai kompetensi teknis". Dalam kenyataannya Ideologi gender yang dikontruksi masyarakat menempatkan perempuan sebagai jenis kelamin kelas dua. Laki-laki diorientasikan ke bidang publik, sebagai kepala keluarga, bertanggung jawab memenuhi ekonomi keluarga, yang dianggap mempunyai nilai sosial-ekonomis tinggi, sebagai institusi utama dalam masyarakat modern. Sedangkan perempuan pada bidang domestik (bertanggung jawab terhadap pemeliharaan keluarga dan tugas dalam Rumah Tangga) yang dianggap kurang mempunyai nilai sosial-ekonomi. Struktur hubungan gender yang timpang ini diciptakan atau dipertahankan tidak terlepas dari kepentingan sekelompok orang yang menguasai 
sumberdaya ekonomi (kapitalis) maupun sistem sosial-ekonomi yang partriarkhi (Abdullah, 1995: 5; Saptari \& Holzner, 1997:207).

Kajian pustaka tentang pengaruh pariwisata dalam proses pembangunan memperlihatkan perhatian yang kecil pada pengaruh pariwisata bagi peran perempuan dalam dinamika sosial. Beberapa penelitian mencatat bahwa pariwisata turut andil dalam perubahan gender perempuan di beberpa tempat, sedangkan penelitian yang lain memperlihatkan bahwa pariwisata memperluas kesempatan perempuan untuk lebih berperan dalam bidang ekonomi, sosial bahkan politik. Di beberapa tempat perempuan lebih berperan dalam perubahan ekonomi yang dibawa pariwisata dan mendapatkan keuntungan dari perubahan ini dibandingkan laki-laki (Brown \& Switzer, 1991 dalam Wiwik, 1997). Walaupun demikian banyak penelitian telah mengungkapkan pula dampak negatif pariwisata pada perempuan. Pembahasan dampak negatif ini berkisar pada eksploitasi perempuan kerana pelacuran dan pelecehan seksual dalam kegiatan pariwisata (Truong, 1990; Holden, Horlemann, Plaffin, 1985).

Indonesia sesungguhnya telah menempatkan posisi perempuan pada level yang sejajaar dengan laki-laki, terutama dalam masalah ketenagakerjaan, karena disadari atau tidak perempuan mempunyai peran ekonomi yang sangat penting dalam pembangunan nasional. Bila melihat fenomena yang berkembang saat ini masalah ketenagakerjaan wanita terlihat ada berbagai kesenjangan walaupun undang-undang ketenagakerjaan telah menjamin segala hak dan kewajibannya. Maih banyak perusahaan yang mempekerjakan perempuan di luar peraturan yang ada. Mereka masih diperlakukan tidak adil dan hak-haknya sebagai pekerja dilanggar seperti terjadi diskriminasi, bahkan sampai kepada pelecehan seksual. Ironisnya kenyataan seperti itu jarang sekali terungkap sehingga memberi peluang kepada pihak pengusaha untuk terus mempekerjakan perempuan meski masih dalam kondisi yang memprihatinkan.

Ketidakadilan yang menimpa kaum perempuan akan memunculkan persepsi bahwa perempuan dilahirkan untuk melakukan pekerjaan-pekerjaan yang jauh lebih terbatas jumlahnya dengan status pekerjaan yang rendah serta dengan imbalan (upah/ gaji) yang rendah pula. Pekerjaan perempuan selama ini umumnya terbatas pada sektor rumah tangga (domestik). Walaupun para perempuan mulai menyentuh pekerjaan di sektor publik, jenis pekerjaan tersebut merupakan perpanjangan dari pekerjaan rumah tangga misalnya bidan, juru rawat, guru, sekretaris dan pekerjaan lainnya yang lebih banyak memerlukan keahlian manual. Begitu pula 
mengenai upah dan gaji sudah menjadi rahasia umum jika upah pekerja perempuan lebih rendah dari pekerja laki-laki untuk jenis pekerjaan yang sama.

Meskipun prospek pekerja perempuan cukup baik dilihat dari pertumbuhan angkatan kerja perempuan lebih cepat dari angkatan kerja laki-laki, namun tuntutan persamaan hak atas perolehan upah atau gaji dengan laki-laki belum sepenuhnya berhasil. Hal ini disebabkan oleh selain sumberdaya pekerja perempuan masih rendah juga disebabkan oleh absentisme dan pemutusan hubungan kerja di kalangan pekerja perempuan cukup tinggi. Akibatnya pihak perusahaan enggan menginvestasikan sumberdaya mereka untuk memberikan pendidikan dan pelatihan kepada pekerja perempuan.

Sementara pekerja perempuan yang bekerja pada malam hari selama ini masih mengalami berbagai kendala yang dapat diartikan bahwa kaum perempuan belum saatnya untuk mandiri secara total. Misalnya pekerja perempuan tidak bisa bekerja dalam kondisi sedang hamil, harus mendapat ijin dari suami, keluarga dan perusahaan harus menyediakan angkutan antar jemput. Di dalam keluarga biasanya laki-laki mendapatkan perhatian yang lebih dibandingkan perempuan. Hal ini sangat jelas pada keluarga dengan kondisi ekonomi yang sulit. Orang tua cenderung memilih anak laki-laki untuk melanjutkan studi daripada anak perempuan sehingga pada akhirnya akan berdampak kepada perbedaan pengetahuan dan kemampuan (Sumanto, 1993).

Kaum perempuan mengalami diskriminasi tidak saja di sektor domestik, di sektor publikpun perempuan mengalami hal yang sama. Sangat jarang pada masyarakat industri yang perempuannya secara ekonomis setara dengan laki-laki, karena era industrialisasi sangat kental dengan bias jender berdasarkan perbedaan jenis kelamin. Sistem ekonomi industri kapitalis mengutamakan pertumbuhan dan mendorong konsumsi justru menimbulkan diskriminasi terhadap perempuan.

Diskriminasi di bidang ekonomi dapat dilihat dari kesenjangan upah yang diterima perempuan dibanding laki-laki. Kesenjangan tersebut dapat dilihat pada setiap kategori seperti tingkat pendidikan, jam kerja dan lapangan pekerjaan. Semakin rendah tingkat pendidikan perempuan maka semakin besar kesenjangan upah yang diterima terhadap laki-laki.

Secara umum dapat diungkapkan bahwa perempuan Indonesia sudah mencapai kemajuan yang nyata dalam pendidikan, kesempatan kerja dan keterlibatan dalam berbagai aspek kehidupan 
lainnya. Namun, jika diamati lebih mendalam akan dijumpai kenyataan bahwa kesempatan yang diperoleh perempuan masih tertinggal dibanding dengan laki-laki.

Hal tersebut mengisyaratkan bahwa di dalam masyarakat yang diwarnai oleh emensipasi yang sudah maju sekalipun, karakteristik pekerjaan perempuan dan laki-laki tidak ditentukan oleh faktor yang sama. Berbagai jenis pekerjaan dianggap cocok dengan karakteristik perempuan contohnya seperti pekerjaan yang membutuhkan kesabaran dan ketelatenan. Keterbatasan peluang kerja perempuan berkaitan erat dengan modal yang dimiliki oleh tenaga kerja perempuan yang secara umum dapat dikatakan human capital perempuan yang meliputi pendidikan, latihan dan pengalaman relatif masih rendah. Kondisi seperti itu juga dirasakan oleh tenaga kerja perempuan di sektor pariwisata dihadapkan pada persoalan dilematis peran ganda antara keluarga dan profesi.

\section{PENUTUP}

Sektor pariwisata telah mampu menciptakan kesempatan kerja melalui berbagai jenis usaha yang terkait dengan kepariwisataan yang dapat dimanfaatkan oleh pekerja baik laki-laki maupun perempuan. Walaupun pekerja perempuan sudah banyak terlibat dalam berbagai kegiatan di sektor pariwisata tetapi berbagai permasalahan gender selalu menyertainya yang membatasi perempuan di ranah publik seperti berbagai bentuk marjinalisasi diskriminasi dan subordinasi yang tercermin pada kesenjangan upah atau gaji, terkonsentrasinya pekerja perempuan pada jenis-jenis pekerjaan secara manual yang tidak memerlukan pendidikan dan keterampilan yang tinggi.

Potensi perempuan sebagai bagian dalam menunjang pembangunan nasional tidak dapat disangkal lagi, terutama sektor pariwisata. Semakin banyak diminati oleh pekerja perempuan, karena dunia kerja pariwisata menuntut adanya suatu sikap keramah-tamahan yang biasanya dimiliki pekerja perempuan secara alamiah.

Peran ganda bagi pekerja perempuan yang sudah menikah menjadi dilematis, di satu sisi mereka sebagai ibu rumah tangga yang harus piawai mengatasi urusan rumah tangganya dan di sisi lain mereka harus profesional dalam meniti karier.

Pariwisata sebagai perjalanan di waktu luang (leisure travel) dan sebagai industri yang mendukung dibentuknya hubungan-hubungan manusia sehingga dipengaruhi oleh hubungan gender yang bersifat lokal maupun global (Swain, 1995). Hubungan di dalam dan antar host dan 
guaet bisa dianalisis dengan berfokus pada beragam karakteristik termasuk gender, kelas, usia, etnis, dan ras serta negara. Pembangunan pariwisata mempengaruhi perubahan sistem nilai karena host dan guest saling bertemu satu sama lain dan interaksi gendernya membentuk persepsi dan perilaku gender yang berbeda pula. pembedaan ini saling terjalin dan membentuk studi yang kompleks.

Studi-studi teoritis tentang pariwisata dan hubungan sosial belakangan ini belum melibatkan isu gender secara subtansial. Walaupun demikian kegiatan wisata erat kaitannya dengan transformasi kerja berupah (paid work) yang mengarahkan Kinnaird (1994; 4) pada pertanyaan fundamental tentang pembagian kerja baik yang berupah maupun tidak (unpaid work) dan implikasinya pada hubungan gender baik bagi host maupun guest.

Beberapa penelitian pariwisata dengan pembangunan pariwisata telah menemukan macam dan dampaknya pada peluang kerja, berupa mempertegas pembagian kerja gender atau mengubahnya sesuai dengan munculnya peluang kerja atau penghasilan baru, bahwa kesempatan kerja yang diberikan kepada perempuan terbatas pada pekerjaan yang tidak membutuhkan keterampilan serta upah rendah.

\section{DAFTAR PUSTAKA}

Anolaga, Pandji. Psikologi Kerja.Jakarta:Rineke Cipta 1992.

Biro Pusat Statistik. Hasil Sensus Penduduk 2005. Jakarta: 2007.

Bagguley, Rees \& Fielder, 1992, Levy \& Lerch, 1991; Monk \& Alexander, 1996.

Fakih, Mansour. Gender sebagai Alat Analisis Sosial. Jakarta: 1996.

Hafidz, Wardah. Pola Relasi Gender dan Permasalahannya. Yogyakarta: 1995.

Iqbal, Mohammad. Wanita Kepala Rumah Tangga dan Kemiskinan. Jakarta: 1994.

Notosusanto, Smit. Penghapusan Diskriminasi Perempuan. Jakarta: 1994.

Sumanto, Ali. Nasib Pekerja Wanita di Bawah Pria. Bali: 1993.

Suryadi, Endang T. Wanita Karier dan Dilemanya. Jakarta:Gramedia, 1989.

Kinnaird, V. and Hall, D (Eds). Understanding Tourism Processes: gender-aware framework. Tourism Management Vol. 17(2), 1994.

Scheyvens, R. Promoting Women's Empowerment Through Involvement in Ecotourism: Experiences from the Third World. Journal of Sustainable 2000. 